Article

\title{
Predicting the Commitment of Volunteers' Environmental Stewardship: Does Generativity Play a Role?
}

\author{
Chen Ding ${ }^{1}$ and Michael A. Schuett ${ }^{2, *}$ \\ 1 School of Physical Education, Huazhong University of Science and Technology, Wuhan 430074, China; \\ chending@hust.edu.cn \\ 2 Department of Recreation Park and Tourism Sciences, Texas A\&M University, College Station, TX 77843, USA \\ * Correspondence: mschuett@tamu.edu
}

Received: 7 July 2020; Accepted: 19 August 2020; Published: 21 August 2020

\begin{abstract}
This study examined factors that contribute to the commitment of volunteers' environmental stewardship through motivations, satisfaction, and generativity. Generativity, a focus on the next generation, has not been examined in the content of environmental stewardship. Volunteers for the Texas Parks \& Wildlife Department (TPWD) were surveyed online from May to September of $2016(n=1111)$. Through structural equation modeling (SEM) analysis, our findings validated six categories of motivations (helping the environment, project organization, values, learning, career, and social), four dimensions of satisfaction (organizational support, project organization, sense of empowerment, and group integration), and two factors of commitment (affective commitment and normative commitment). Our findings showed positive and significant path correlations for four latent variables (motivations, satisfaction, commitment, and generativity). This study contributes to the literature by showing the potential for generativity to contribute to environmental stewardship, and by enhancing stewardship efforts for agencies and organizations in recruiting and engaging volunteers.
\end{abstract}

Keywords: environmental stewardship; generativity; commitment; volunteers

\section{Introduction}

Volunteers play a pivotal role in assisting public and nonprofit organizations to accomplish their goals and assist with daily operations [1]. According to the Bureau of Labor Statistics (2016) [2], from September 2014 to September 2015 approximately 62.6 million people age 16 and over $(24.9 \%$ of that demographic group) volunteered with an organization. Empirical analysis showed that the economic value of volunteer service in that single year was substantial, reaching nearly USD 184 billion [3]. These numbers underscore some of the significant temporal and economic contributions that volunteers make annually. This level of commitment accentuates the role volunteering plays for individuals, communities and society [4].

Park and natural resource management agencies are often major beneficiaries of volunteering activities. Volunteering has been used as a strategic approach to overcome the dilemma between the fiscal constraints that natural resource management agencies (e.g., U.S. Forest Service) are currently facing and the tasks they need to accomplish [5]. The past quarter-century's fiscal constraints have led natural resource management agencies (e.g., U.S. Forest Service and Bureau of Land Management) to be increasingly dependent upon volunteer work as a critical resource [6,7]. For example, by 2015, the National Park Service (NPS) had a significant maintenance backlog of nearly USD 12 billion, which resulted in reduced resource protection, deferred maintenance, and trail and road closures [8]. Environmental stewardship activities provide assistance with park and natural resource management 
agencies in various types of work, such as restoring ecosystems, monitoring resources, citizen science, policy planning, and decision-making [9]. By involving volunteers, agencies obtain the benefit of getting essential work completed and reducing personnel expenses. Therefore, for park and natural resources management agencies, which heavily rely upon volunteers to accomplish numerous environmental stewardship activities, uncovering the reasons why people volunteer and stay engaged are critical for agencies to get work completed [7].

Recent research has suggested that there is an increase in the number of urban and rural stewards caring for and improving local environmental conditions in the United States [10,11]. The benefits that volunteers gain from their experiences in doing stewardship activities include helping the environment, socializing with people with similar values and improving areas that volunteer use for their own recreation [7]. Many of these projects that volunteers are engaged with are geared toward future conditions, e.g., restoration, planning, and monitoring, as well as modern information technologies based on new types of wireless sensors [12,13].

Generativity is a concept used to describe 'the concern in establishing and guiding the next generation' [14]. Volunteering as an environmental steward is very future-oriented, targeting the next generation (e.g., tutoring next generation the environmental skills) or preserving and improving the natural environment for posterity [15]. Given the potential relationship between generativity and participation in environmental stewardship, it is reasonable to believe that investigating generativity in volunteering would enhance our understanding of who will provide sustained volunteer service and how they will benefit from their experiences (e.g., [16-18]). However, the relationship between generativity and environmental stewardship has yet to be studied sufficiently. Thus, the goal of this research is to examine the role of generativity in volunteering in environmental stewardship activities.

\section{Literature Review}

\subsection{Volunteering in Environmental Stewardship Activities}

Although many volunteers donate their time and energy to natural resource management agencies, little research has addressed the psychological aspects of volunteering in environmental stewardship activities [7]. Evidence suggests that it is inadequate for public agencies to simply use volunteers without knowing why they do it or what they get out of the experience $[19,20]$. A lack of knowledge about their psychology (e.g., satisfaction, personal rewards, and level of commitment) can restrict an agencies' ability to efficiently administer and maintain the stewardship programs that involve volunteers [21,22]. In order to attain the full benefits of volunteering activities, provided that volunteers come in advance and are properly trained through courses on environmental issues, program managers should be more familiar with certain psychological aspects of their volunteers, such as the reasons that motivate individuals to donate their time and effort [23], expectations regarding the volunteering experience, and how well volunteers emotionally bond with the agencies [7].

Although the literature on volunteering is extensive, its focus on those who volunteer to participate in environmental stewardship with environmental organizations or natural resource management agencies has not kept pace [24]. In order to better understand why individuals are engaged in environmental stewardship, this research will examine key factors that contribute to commitment by volunteers.

\subsection{Functional Approach}

A variety of factors can encourage an individual to provide their time and effort voluntarily [25]. Researchers have attempted to understand motivating factors in the context of volunteering based on several theories. For example, the theory of altruism and selflessness describes people who engage in volunteer behavior because they want to help others [26]. Exchange theory is focused on personal reward for volunteering. Volunteering can be used to fulfill the desires of gaining benefits, such as social status or friendships [27]. 
Within the literature of volunteering in environmental stewardship activities, the functional approach has been widely applied to understand their motivations along with the benefits people obtain from volunteering [5]. This approach suggests that individuals fulfill personal or social goals by getting involved in volunteering activities [28,29]. Based on this earlier body of research, Clary et al. (1998) [30] developed the Volunteer Function Inventory (VFI). This inventory proposes six types of functions for volunteerism: the expression of altruistic values, learning and understanding, social goals, career development, protecting ego from negative feelings, and seeking personal growth. There is evidence to suggest that people volunteer in environmental stewardship activities in order to fulfill these desires as well as protect the environment [23,31-33].

In a study of the Florida Fish and Wildlife Conservation Commission (FWC), Jacobson, Carlton, and Monroe (2012) [23] found that the strongest motivation for volunteering for environmental stewardship activities was helping the environment, followed by learning about nature, enhancing areas that volunteers used or enjoyed, and expressing respect and values. Other studies have also found these motivating factors. Bruyere and Rappe (2007) [7] incorporated items from the VFI [30] and other scales to investigate individuals who had voluntarily served a natural resource organization. They found that volunteers were primarily motivated by desires to help the environment, express their values, and learn about nature. By adopting the VFI [30], researchers have found that people volunteer for a wide variety of reasons. Moreover, compared to volunteering with social services sectors, volunteer stewards are interested in being civically engaged and desire maintaining and improving the environment [34].

\subsection{Volunteer Motivation, Satisfacion, and Commitment}

Previous research on the antecedents of volunteering provides valuable information to explain why people initially become engaged in volunteer activities. However, this line of research is limited and does not provide sufficient information regarding the dynamic nature of volunteerism and other factors that may contribute to its understanding.

Natural resource management agencies regularly face challenges associated with using volunteer services, such as high volunteer turnover and unreliability [8,35]. Situations like this require agencies to expend extra effort to recruit and train new volunteers [36,37]. Therefore, increasing volunteers' long-term commitment to a nonprofit organization is a crucial responsibility for managers [38]. To uncover a deeper understanding about why volunteers are willing to work at a particular organization or program for an extended period of time, researchers need to consider additional components (e.g., volunteer satisfaction and retention) when investigating volunteering [39]. By doing so, organizational managers could target specific markets for recruitment or improve retention strategies (e.g., seniors and rewards) [5].

A few research studies have focused on the interrelatedness of volunteer stewards' motivations, satisfaction, and commitment. For example, Hunter (2010) [40] exclusively drew participants from 17 environmental operations and employed the Volunteer Life Cycle [41]. The goal was to understand the best means of building and maintaining a useful level of volunteer dedication. This study suggests that volunteers' satisfaction with their experience has a positive impact on their commitment to an organization, and their levels of satisfaction are driven by the organizations' ability to live up to volunteers' motivations. Findings from Hunter's (2010) [40] research showed detailed information on how to improve volunteers' motivations, satisfaction, and engagement. Organizations may be able to mitigate problems of volunteer turnover based on the study's findings, although this issue can be agency specific.

\subsection{Generativity and Volunteerism}

Past studies have combined the theories of functionalism, satisfaction, and commitment in trying to understand volunteers' past and current attitudes and behaviors (e.g., [42]). However, studies that have integrated the theory of generativity into a conceptual framework explaining 
the dynamic nature of volunteerism are limited [43-45]. Originally developed by Erikson (1963; 1982) $[14,46]$, generativity is a concept used to describe 'the concern in establishing and guiding the next generation' [14]. Volunteering as an environmental steward is future-oriented, targeting the next generation (e.g., teaching environmental skills) or preserving and improving natural environment for posterity [15]. Such pro-environmental behavior fits the core of generativity, focusing on the improved welfare of impending generations [47,48]. Researchers have hypothesized that generative interests promote generative behaviors [49]. Snyder and Clary (2004) [50] studied the relationships between generativity and volunteering motives. They found that generativity and volunteering motivations were moderately associated, indicating that generativity might be a predictor of volunteering motives.

There is evidence for a connection between generativity and environmental stewardship. For instance, Urien and Kilbourne (2011) [15] found that in comparing individuals with varying levels of generativity, those with a higher level were more likely to act in an environmentally responsible manner. It is important to note, though, that this study was based on a sample made up exclusively of university students. Similarly, Warburton and Gooch (2007) [51] conducted a qualitative study on a sample of older adults (ages 55+) who volunteered for environmental stewardship groups in Australia. The study's purpose was to examine the relationship between generativity and pro-environmental behavior. Their findings suggested that participants perceived their environmental actions as a lasting legacy involving a long-term improvement in the environment, their personal growth regarding learning and understanding, and the passage of knowledge to a younger generation. This study provided empirical support for connections between generativity and pro-environmental behavior in older adults.

Selecting from about one hundred Italian experiences, Cossetta and Cappelletti (2013) [52] examined three cases of social innovation with a focus on generativity. This study aimed to manifest the generative processes of social innovation through the analysis of those movements originating various forms of socially shared values. The A2020 Association, one of three cases, successfully raised the whole community's (Morbegno, a town in Valtellina area) awareness of the need for sustainable lifestyles and the welfare of future generations. A2020's ability to intercept "generativity", an unexpressed demand for participation, enabled the whole community to tune in, which in turn made A2020 participative, constructive, collaborative, and productive. This study demonstrated how social innovation is generatively shaped and the significance of generativity in supporting the ecosystem and local community.

Given the potential relationship between generativity and participation in environmental stewardship, it is plausible to believe that including generativity would substantially increase the predictive utility of determining who will provide sustained volunteer service (e.g., [16-18]). However, the relationship between generativity and environmental stewardship has yet to be studied sufficiently. The current study adds to the literature by exploring the role of generativity as a predictor of volunteers' motivations, satisfaction, and commitment within the context of environmental stewardship.

\subsection{Research Hypotheses}

The goal of this paper is to identify the effects of volunteers' motivations, satisfaction, and generativity on volunteer commitment to one natural resource management agency, the Texas Parks \& Wildlife Department (TPWD). Specifically, this investigation was premised on the following hypotheses:

Hypothesis 1 (H1). Volunteers' motivations positively affect volunteer satisfaction.

Hypothesis 2 (H2). Volunteers' motivations positively affect volunteer commitment.

Hypothesis 3 (H3). Volunteers' satisfaction positively affects volunteer commitment.

Hypothesis 4 (H4). Volunteers' generativity positively affects volunteer motivations. 
Hypothesis 5 (H5). Volunteers' generativity positively affects volunteer satisfaction.

Hypothesis 6 (H6). Volunteers' generativity positively affects volunteer commitment.

Overlapping volunteer theories under the umbrella of one conceptual framework was used to explore new perspectives about volunteer stewards. Knowledge generated from this study will uncover new perspectives about volunteerism to assist program managers to improve nature-based programs that may help recruit, satisfy, and retain volunteers.

\section{Method}

\subsection{Study Population}

This study's population consisted of volunteers for the Texas Parks \& Wildlife Department (TPWD). TPWD is the state agency responsible for overseeing the protection of wildlife and wildlife habitats, including its state parks. Visitors to Texas state parks or other protected areas can participate in a wide range of outdoor recreation activities, including fishing, hunting, wildlife observation, and interpretive activities [53]. The TPWD volunteer program manager provided their volunteer database for the sampling frame containing a list of registered volunteers from 2011 to 2016 . The sample was limited to volunteers who had participated at least once in TPWD volunteer programs during the past two years. Examples of stewardship activities in which volunteers participate include biological inventories, visitor education, interpretive programs, and environmental restoration. After excluding any volunteers 17 years old and under, duplicate email addresses, and email addresses of volunteers requesting removal from the mailing list, a sample of 5936 remained.

\subsection{Data Collection}

A web-based program (Qualtrics) was employed to collect data. Before the authors administered the survey, a personalized email was sent out to potential respondents in the TPWD volunteer database introducing the study and inviting them to complete the online questionnaire. After the initial email, three reminders were sent out one week apart for a total of four contacts to the sample. The questionnaire was online from May of 2016 to September of 2016.

\subsection{Survey Instrument}

The survey instrument was developed by authors at Texas A\&M University in collaboration with TPWD. TPWD staff reviewed the questionnaire and pilot-tested it with 20 volunteers to ensure readability, content and language. The questionnaire consisted of five parts measuring the following variables: motivations, satisfaction, commitment, generativity, and socio-demographics. The motivation scale (Table 2) included 24 items (e.g., "I volunteer because I am concerned about the environment") adapted from several studies [7,54]. A satisfaction index (Table 3) was composed of 18 items (e.g., "The fit of the volunteer work to my skills and interests") derived from the Volunteer Satisfaction Index [36]. The commitment construct (Table 4) was measured with 13 items (e.g., "TPWD volunteer program has a great deal of personal meaning for me") developed by Allen and Meyer (1990) [55]. The generativity index (Table 5) contained 15 items (e.g., "I have made and created things that have had an impact on other people") selected from the Loyola Generativity Scale [56]. All items were measured on a five-point Likert scale ranging from $1=$ strongly disagree to $5=$ strongly agree. The remaining questions were six items measuring socio-demographics.

\subsection{Analysis}

Structural equation modeling (SEM) using a two-step approach [57] in Linear Structural Relations (8.8 version) was used to test the research hypotheses. First, a confirmatory factor analysis with maximum likelihood (ML) estimation was performed to identify underlying factors of the importance 
of motivations, satisfaction, and commitment. Second, the hypothetical relationships among the constructs were tested simultaneously to determine the predictive utility of the constructs. The overall model fit was determined by various goodness-of-fit statistics, as well as its chi-square value. Specially, the goodness-of-fit statistics include the comparative fit index (CFI) $\geq 0.95$ [58], root mean square error of approximation (RMSEA) $\leq 0.08$ [59], non-normed fit index (NNFI) $>0.95$ [60], and standardized root mean square residual $(\mathrm{SRMR}) \leq 0.08$ [61].

\section{Results}

\subsection{Volunteer Respondents' Profile}

As a result of the introductory email, 418 email addresses were removed from the mailing due to bad addresses and requests to be deleted from the volunteer list. Of the 2845 questionnaires that were returned, 135 were incomplete (missed two-thirds of the items). The authors also deleted 1599 respondents who reported themselves as Texas Master Naturalists (TMN). Texas Master Naturalists are not TPWD volunteers because they are required to donate time to an agency/organization annually to keep their certification. Thus, the effective response rate was $45.8 \%$ (1111/2425).

As shown in Table 1, the participants were $56.0 \%$ male, 38.6\% were between the ages of 60 and 69 (the average age was 59 years), 86.2\% were Caucasian, and just over half (58.4\%) completed a university or post-graduate degree. In regard to employment status, $56.2 \%$ were retired and $29.3 \%$ were employed full-time. As for income, $52.4 \%$ of the respondents had annual incomes higher than USD 60,000. The average number of hours spent volunteering at TPWD in 2015 was $92.3 \mathrm{~h}$. Table 1 shows the volunteers' sociodemographic characteristics.

Table 1. Volunteers' sociodemographic characteristics.

\begin{tabular}{|c|c|c|}
\hline Variable & $\mathbf{N}$ & Percent \\
\hline \multicolumn{3}{|l|}{ Gender } \\
\hline Male & 618 & 56.0 \\
\hline Female & 485 & 44.0 \\
\hline \multicolumn{3}{|l|}{ Age } \\
\hline Under 20 & 9 & 0.8 \\
\hline $20-29$ & 61 & 5.7 \\
\hline $30-39$ & 72 & 6.7 \\
\hline $40-49$ & 94 & 8.8 \\
\hline $50-59$ & 171 & 16.0 \\
\hline $60-69$ & 413 & 38.6 \\
\hline $70-79$ & 234 & 21.9 \\
\hline 80 and above & 15 & 1.4 \\
\hline Total & 1069 & 100 \\
\hline \multicolumn{3}{|l|}{ Education } \\
\hline Some high school or less & 9 & 0.8 \\
\hline High school graduate & 89 & 8.1 \\
\hline Some college/Technical school & 358 & 32.7 \\
\hline University Graduate & 359 & 32.8 \\
\hline Post-graduate degree & 281 & 25.6 \\
\hline Total & 1096 & 100 \\
\hline \multicolumn{3}{|l|}{ Employment Status } \\
\hline Employed full time & 322 & 29.3 \\
\hline Employed part time (less than $32 \mathrm{~h}$ per week) & 70 & 6.4 \\
\hline Unemployed and looking for work & 21 & 1.9 \\
\hline Unemployed but not looking for work & 21 & 1.9 \\
\hline Retired & 618 & 56.2 \\
\hline Other & 48 & 4.4 \\
\hline Total & 1100 & 100 \\
\hline
\end{tabular}


Table 1. Cont.

\begin{tabular}{ccc}
\hline Variable & N & Percent \\
\hline Income (USD) & & \\
Under 20,000 & 60 & 6.3 \\
$20,000 \sim 39,999$ & 173 & 18.1 \\
$40,000 \sim 59,999$ & 223 & 23.3 \\
$60,000 \sim 79,999$ & 169 & 17.7 \\
$80,000 \sim 99,999$ & 106 & 11.1 \\
$100,000 \sim 119,999$ & 90 & 9.4 \\
$120,000 \sim 139,999$ & 53 & 5.5 \\
$140,000 \sim 159,999$ & 39 & 4.1 \\
160,000 and above & 44 & 4.6 \\
Total & 957 & 100 \\
Race/Ethnicity & & \\
African-American or Black & 27 & 2.5 \\
Asian & 11 & 1.0 \\
Caucasian or White & 928 & 86.2 \\
Latino/Hispanic & 74 & 6.9 \\
Other & 37 & 3.4 \\
Total & 1077 & 100 \\
\hline
\end{tabular}

\subsection{Confirmatory Factor Analysis}

\subsubsection{Identification of Motivational Factors}

As demonstrated in Table 2, all fits for the motivational measurement model were good. Specifically, $\chi^{2}(237)=1822.30, \mathrm{CFI}=0.96, \mathrm{RMSEA}=0.07, \mathrm{NNFI}=0.96$, and SRMR $=0.05$. Cronbach's alpha of each motivational construct was greater than 0.70 , indicating a good convergent validity $[62,63]$. In addition, the standardized path loading of each item was greater than 0.4 . Therefore, the six-factor (e.g., helping the environment, project organization, values, learning, career, and social) motivation model was accepted and further modification was unnecessary.

Table 2. Confirmatory factor analysis of the motivation construct.

\begin{tabular}{|c|c|c|}
\hline & Mean (SD) & $\lambda$ \\
\hline Helping the environment $(\alpha=0.91)$ & $3.94(0.90)$ & \\
\hline I volunteer because I am concerned about the environment & & 0.77 \\
\hline Volunteering allows me to protect natural areas from disappearing & & 0.86 \\
\hline I volunteer because I can help preserve natural areas for future generations & & 0.87 \\
\hline I volunteer because I want to see improvements to the environment & & 0.87 \\
\hline Learning $(\alpha=0.86)$ & $3.86(0.87)$ & \\
\hline Volunteering lets me learn things through direct, hands-on experience & & 0.70 \\
\hline Volunteering provides an opportunity for learning about specific plants/animals & & 0.79 \\
\hline I volunteer because it allows me to learn about the environment & & 0.89 \\
\hline Volunteering allows me to observe nature & & 0.72 \\
\hline Values $(\alpha=0.79)$ & $3.62(0.87)$ & \\
\hline By volunteering I feel better about myself & & 0.68 \\
\hline I volunteer because I can express my values through my work & & 0.72 \\
\hline Volunteering makes me feel needed & & 0.63 \\
\hline Volunteering allows me to live in a way that represents my values & & 0.74 \\
\hline Project organization $(\alpha=0.86)$ & $3.50(0.91)$ & \\
\hline Volunteering for TPWD provides me with the opportunity to work with good leaders & & 0.74 \\
\hline I enjoy volunteering for TPWD because I know what is expected of me & & 0.68 \\
\hline I enjoy volunteering for TPWD because I can be part of a well-organized project & & 0.87 \\
\hline I volunteer because TPWD volunteer programs are well-organized & & 0.82 \\
\hline
\end{tabular}


Table 2. Cont.

\begin{tabular}{|c|c|c|}
\hline & Mean (SD) & $\lambda$ \\
\hline Social $(\alpha=0.70)$ & $2.82(0.84)$ & \\
\hline My friends volunteer & & 0.42 \\
\hline Volunteering provides me with the opportunity to meet new people & & 0.73 \\
\hline Volunteering allows me to be with people like myself & & 0.79 \\
\hline People I'm close to want me to volunteer & & 0.42 \\
\hline Career $(\alpha=0.94)$ & $1.86(1.19)$ & \\
\hline Volunteering may help me to get a foot in the door at a place where I would like to work & & 0.84 \\
\hline Volunteering allows me to make contacts that might help my career & & 0.92 \\
\hline Volunteering helps me to explore possible career options & & 0.94 \\
\hline Volunteering will help me to succeed in a chosen profession & & 0.87 \\
\hline
\end{tabular}

Note: Values are mean scores on a five point scale: 1 = "Not At All Important" and 5 = "Extremely Important".

The ranking of these subscales by mean scores were helping the environment $(\mathrm{M}=3.94)$, learning $(M=3.86)$, values $(M=3.62)$, project organization $(M=3.50)$, social $(M=2.82)$, and career $(M=1.86)$. Table 2 shows the confirmatory factor analysis of the motivation construct.

\subsubsection{Identification of Satisfaction Factors}

As shown in Table 3, all the fit indices of the satisfaction measurement model met the criteria suggested from the literature (e.g., [60-62]). Specifically, $\chi^{2}(129)=1148.27, \mathrm{CFI}=0.98$, RMSEA $=0.08$, $\mathrm{NNFI}=0.97$, and SRMR $=0.04$, representing a reasonable fit to these sample data. The Cronbach's alpha value of each factor had adequate value (ranging from 0.80 to 0.93 ), and all factor loadings were significant. The factors confirmed were participation efficacy, group integration, sense of empowerment, and organizational support. Among the four subscales, participants were most satisfied with participation efficacy $(M=4.27)$ and least satisfied with organizational support $(M=3.99)$. Overall, participants were satisfied with their volunteering experiences with a mean score for each factor higher than 3 (see Table 3). Table 3 shows the confirmatory factor analysis of the satisfaction construct.

\subsubsection{Identification of Commitment Factors}

A confirmatory factor analysis (CFA) procedure was conducted to test the validity of the two-factor structure of commitment to TPWD. The goodness-of-fit indices showed that the hypothesized model was a poor fit to these sample data. Therefore, it was necessary to re-specify the model. The authors deleted one item with a low magnitude factor loading and allowed two pairs of measurement errors of observed correlated variables. After modifying, the fit indices of the modified commitment measurement model showed a satisfactory fit to these sample data. Specifically, $\chi^{2}(50)=381.25$, $\mathrm{CFI}=0.98, \mathrm{RMSEA}=0.07, \mathrm{NNFI}=0.97$, SRMR $=0.04$. As displayed in Table 4 , the Cronbach alphas of these two factors ( 0.85 and 0.81$)$ indicated excellent internal consistency. Between the two sub-dimensions, the findings indicated that the participants perceived their commitment to TPWD as being more affective $(\mathrm{M}=3.91)$ than normative $(\mathrm{M}=3.40)$ (see Table 4$)$. Table 4 shows the confirmatory factor analysis of the commitment construct.

\subsubsection{Descriptive Statistics of Generativity}

Unlike motivations, satisfaction, and commitment, all 15 of the items for the generativity scale assessed a homogeneous construct $[18,64]$. Three items were reverse-coded and used in the analyses: "I do not feel like other people need me;" "In general, my actions do not have a positive effect on other people;" and "I feel as though I have done nothing of worth to contribute to others' lives." Table 5 indicates reported scores on level of generativity; the majority of these items had a mean of approximately 4 or above. Among these fifteen items, the desire to pass along knowledge gained 
through experience had the highest mean $(\mathrm{M}=4.37 ; \mathrm{SD}=0.40)$ (see Table 5$)$. Table 5 shows the descriptive statistics of generativity.

Table 3. Confirmatory factor analysis of the satisfaction construct

\begin{tabular}{|c|c|c|}
\hline & Mean (SD) & $\lambda$ \\
\hline Participation efficacy $(\alpha=0.86)$ & $4.27(0.62)$ & \\
\hline The difference my volunteer work makes & & 0.76 \\
\hline The opportunities I have to learn new things & & 0.72 \\
\hline The fit of the volunteer work to my skills and interests & & 0.82 \\
\hline How worthwhile my contribution is & & 0.82 \\
\hline Group integration $(\alpha=0.93)$ & $4.17(0.71)$ & \\
\hline My relationship with other volunteers & & 0.85 \\
\hline The friendships I have made while volunteering for TPWD & & 0.81 \\
\hline The amount of interaction I have with other volunteers & & 0.98 \\
\hline The amount of time I spend with other volunteers & & 0.89 \\
\hline Sense of empowerment $(\alpha=0.80)$ & $4.14(0.69)$ & \\
\hline The access I have to information concerning TPWD & & 0.75 \\
\hline The freedom I have in deciding where and how to volunteer & & 0.75 \\
\hline The chances I have to utilize my knowledge and skills & & 0.79 \\
\hline Organizational support $(\alpha=0.91)$ & $3.99(0.72)$ & \\
\hline My relationship with paid staff & & 0.70 \\
\hline The way in which TPWD provides me with performance feedback & & 0.78 \\
\hline The support I receive from TPWD & & 0.82 \\
\hline The amount of information I receive about what TPWD is doing & & 0.84 \\
\hline The amount of communication provided to me from paid staff & & 0.76 \\
\hline How often TPWD acknowledges the work I do & & 0.80 \\
\hline The amount of permission I need before I can do my job & & 0.67 \\
\hline
\end{tabular}

Note: Values are mean scores on a five-point scale: 1 = "Very Dissatisfied" and 5 = "Very Satisfied".

Table 4. Confirmatory factor analysis of the commitment construct.

\begin{tabular}{|c|c|c|}
\hline & Mean (SD) & $\lambda$ \\
\hline Affective commitment $(\alpha=0.85)$ & $3.91(0.65)$ & \\
\hline I would be very happy to spend many years with the TPWD volunteer program & & 0.64 \\
\hline I do not feel "emotionally attached" to the TPWD volunteer program & & 0.60 \\
\hline I enjoy discussing my TPWD volunteer program with people outside the agency & & 0.50 \\
\hline I feel as if TPWD volunteer program's problems are my own & & 0.52 \\
\hline I do not feel like "part of the family" at the TPWD volunteer program & & 0.61 \\
\hline TPWD volunteer program has a great deal of personal meaning for me & & 0.82 \\
\hline I feel a strong sense of belonging to the TPWD volunteer program & & 0.89 \\
\hline Normative commitment $(\alpha=0.81)$ & $3.40(0.77)$ & \\
\hline TPWD volunteer program deserves my loyalty & & 0.78 \\
\hline I would feel guilty if I left TPWD volunteer program right now & & 0.68 \\
\hline I owe a great deal to the TPWD volunteer program & & 0.73 \\
\hline I do not feel any obligation to remain with the TPWD volunteer program & & 0.53 \\
\hline $\begin{array}{c}\text { Even if it were to my advantage, I do not feel like it would be right to leave the TPWD } \\
\text { volunteer program right now }\end{array}$ & & 0.56 \\
\hline
\end{tabular}

Note: Values are mean scores on a five-point scale: $1=$ "Strongly Disagree" and $5=$ "Strongly Agree". 
Table 5. Descriptive statistics of generativity.

\begin{tabular}{ccc}
\hline & Mean & (SD) \\
\hline I try to pass along the knowledge I have gained through my experiences & 4.37 & $(0.40)$ \\
I feel as though I have done nothing of worth to contribute to others & 4.30 & $(0.67)$ \\
I try to be creative in most things that I do & 4.07 & $(0.49)$ \\
In general, my actions do not have a positive effect on other people & 4.05 & $(0.74)$ \\
Other people say that I am a very productive person & 4.04 & $(0.46)$ \\
I have a responsibility to improve the neighborhood in which I live & 4.02 & $(0.53)$ \\
I have made many commitments to many different kinds of people, & 3.98 & $(0.69)$ \\
groups, and activities in my life & 3.97 & $(0.69)$ \\
Volunteering is the morally right thing to do & 3.96 & $(0.56)$ \\
I feel as though I have made a difference to many people & 3.91 & $(0.61)$ \\
I have important skills that I try to teach others & 3.87 & $(0.66)$ \\
I do not feel that other people need me & 3.86 & $(0.71)$ \\
People come to me for advice & 3.85 & $(0.52)$ \\
I think I would like the work of a teacher & 3.74 & $(0.63)$ \\
Others would say that I have made unique contributions to society & 3.20 & $(1.38)$ \\
\hline
\end{tabular}

Note: Values are mean scores on a five-point scale: $1=$ "Strongly Disagree" and $5=$ "Strongly Agree".

\subsubsection{Testing the Structural Model}

Before the authors tested the hypothetical relationships among the constructs, the practice of item parceling was conducted to transform second-order latent variables into first order in structural equation modeling (SEM) $[65,66]$. The authors summed the items designed to measure particular facets of constructs and then applied the sum as indicators for the general construct. In the step of testing the structural model, these subscale scores were used as the indicator variables for the underlying latent factors.

The results of a Chi-Square test and selected goodness-of-fit indices for the structural model were $\chi^{2}(83)=736.78, \mathrm{CFI}=0.96, \mathrm{RMSEA}=0.08, \mathrm{NNFI}=0.95, \mathrm{SRMR}=0.04$. Moreover, the model statistics fell within acceptable ranges.

The paths and resulting standardized regression weights of the hypothesized structural equation model indicated that there were positive and significant path correlations among all four latent variables (motivations, satisfaction, commitment, and generativity).

Figure 1 displays a summary of the standardized estimates of the path coefficients. Motivations consisted of six factors (helping the environment, project organization, values, learning, career, and social) positively and significantly correlated with both satisfaction $(\beta=0.40, t=9.68, p<0.001)$ and commitment $(\beta=0.12, \mathrm{t}=3.55, p<0.001)$. Along with motivations, satisfaction was also found to be a significant predictor of respondents' commitment $(\beta=0.65, \mathrm{t}=19.34, p<0.001)$. Generativity significantly and positively influenced respondents' motivations $(\beta=0.53, \mathrm{t}=13.20, p<0.001)$, satisfaction $(\beta=0.27, t=7.28, p<0.001)$, and commitment $(\beta=0.22, t=7.18, p<0.001)$. Figure 1 shows the hypothesized structural model. 


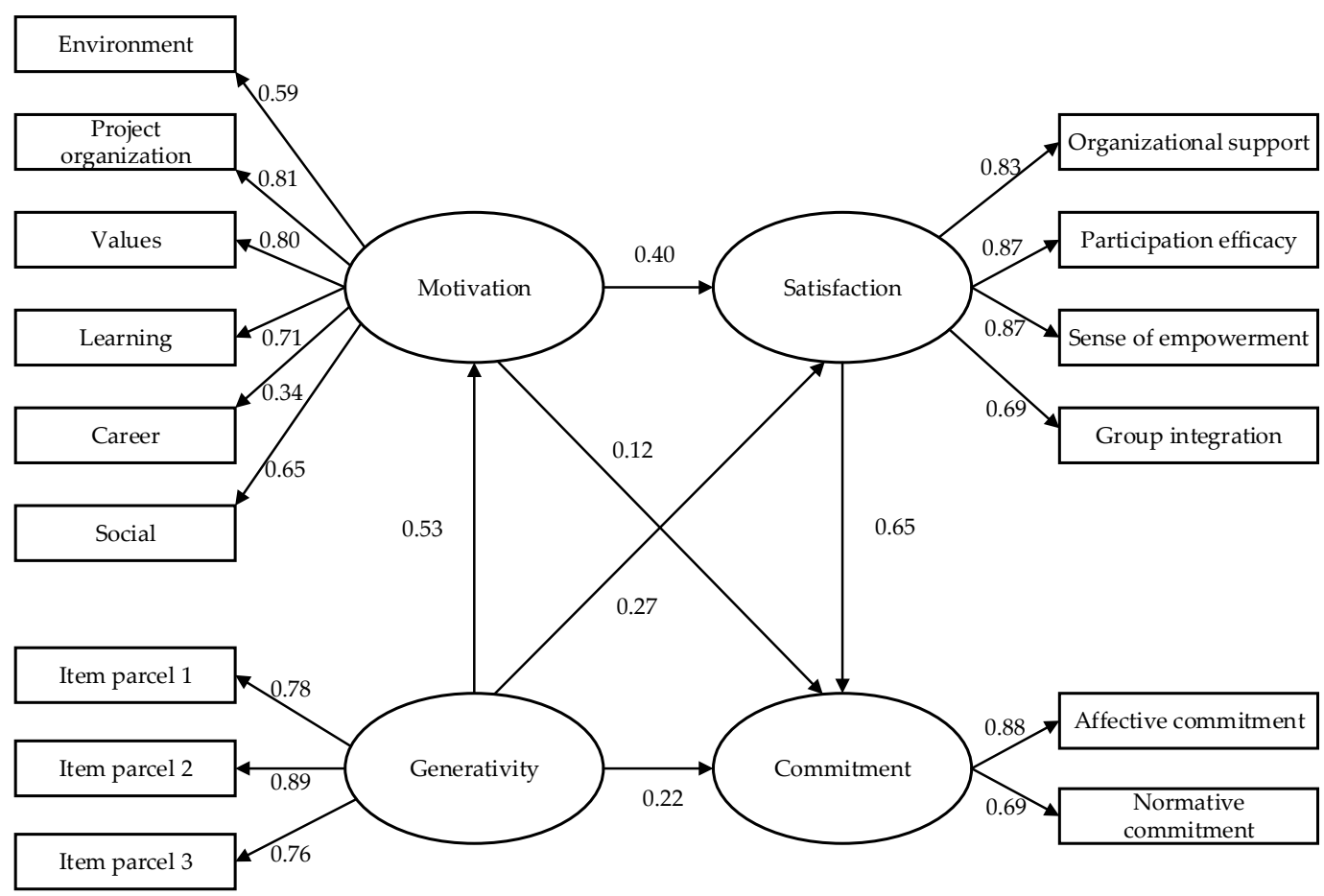

Figure 1. Hypothesized structural model.

\section{Discussion}

This paper focused on the effects of volunteers' motivations, satisfaction, and generativity on volunteer commitment with environmental stewardship activities. All six hypotheses were statistically significant, meaning there were positive path relationships among all the latent variables. This study contributes to the volunteer literature because it showed the potential for generativity to be incorporated into future assessments about volunteers' long-term sustainability and commitment. The results of this study are encouraging for learning more about volunteering in the natural environment. The sample in this study, volunteers from the Texas Parks \& Wildlife Department, is limited to one natural resource management agency. Therefore, a more representative sample of volunteers from other natural resource management agencies, both public and private, should be explored. Our study examined generativity in the context of volunteering, but considering the insufficient body of literature that exists, further development is needed on generativity, its relationship to stewardship participation and the factors that may contribute to this phenomenon.

\subsection{Motivations}

Our findings validated six categories of motivations (helping the environment, project organization, values, learning, career, and social) by using CFA. These six motivation factors are consistent with those explained in previous literature on environmental volunteer motivations $[7,23,54]$. Two factors specific to environmental stewardship (helping the environment and project organization) were identified in this study which supports the use of the VFI from Clary et al. (1998) [30]. Of these motivational factors, "helping the environment" was found to be the strongest motivational factor and "career" was the weakest among the volunteers. The average age of this study's respondents (59 years old) parallels findings from similar studies [7,54,67]. A strong desire to be engaged with the natural environment is an important factor to consider in recruiting and working with older volunteers. Although not examined in this study, a willingness to participate in volunteering in stewardship activities has been shown to increase with a personal request for participation [68]. This approach may not always be possible but can certainly attract volunteers by providing a positive atmosphere when interacting with them and/or having an established volunteer program detailed on a website. 
Another important motivation was project organization. Volunteers will be more attracted to well-organized and established projects that have utilized experienced leadership and developed goals. Seasoned volunteer coordinators and trainers are invaluable in working on field-based projects. These organizational attributes along with competent personnel will bolster volunteer recruitment and retention.

\subsection{Satisfaction}

Through the examination of satisfaction, four dimensions were identified in our results: organizational support, project organization, sense of empowerment, and group integration. These results support the application of the Volunteer Satisfaction Index (VSI) developed by Galindo-Kuhn and Guzley (2001) [36] in the context of environmental stewardship. Moreover, volunteers in the TPWD program were very satisfied with their experience, which is consistent with other studies on environmental stewardship (e.g., [34,69]). Volunteers felt positively about their contribution to TPWD and the friends they made during the experience. Thus, they feel that their knowledge and skills are being utilized and appreciated. At the same time, they are gaining personal and social benefits from their time spent volunteering. The satisfaction scores are positive for the long-term provision of TPWD programs. Satisfied volunteers benefit the agency because they enjoy what they do, like who they are working with, and are not a financial liability for the agency $[36,70]$.

Although not measured in this study, identifying specific programs that volunteers like to be matched with can bring out a sense of accomplishment and identity that would be beneficial in the long-term [71]. Additionally, the satisfaction of being able to contribute valuable data for key projects, e.g., water quality monitoring or ecological restoration, have long-term benefits for volunteers, the agency and the ecosystem [72,73].

\subsection{Commitment}

The validity test for the CFA factorial structure of commitment demonstrated that the original model was a poor fit to these sample data. A few modifications were conducted, including allowing two pairs of error terms correlated and deleting one low factor-loading item. This respecification suggested the importance of conducting future research on testing the validity of commitment factors. The mean scores of two commitment factors showed that volunteers who participated in the environmental volunteer program were, in general, committed to TPWD. Moreover, the mean score for affective commitment was higher than for normative commitment, suggesting that TPWD volunteers in the present study were more psychologically bonded to this natural resource management agency via affective commitment than normative commitment. The importance of the affective component has been identified in previous studies [5,31]. These researchers suggested that affective commitment was a more salient factor in influencing environmental volunteers' decision to continue to provide service to a particular agency than the normative commitment. The volunteers in our study showed a high level of affective commitment of TPWD, which demonstrates their acceptance of TPWD's goals and values, a willingness to exert effort on behalf of TPWD to achieve those goals, and strong emotional attachment to the organization.

\subsection{Generativity}

Based on our findings, TPWD volunteers exhibited high levels of generativity. That means that TPWD volunteers are participating in environmental volunteer opportunities as a mechanism to display their concern for future generations. This finding is supported by research from Urien and Kilbourne (2011) [15], who reported that volunteers who are engaged in environmental stewardship activities were more likely to express generativity than individuals who did not engage in environmental activities.

Our study provides insight about how individuals derive meaning and fulfillment by volunteering as environmental stewards as it relates to future generations. Our findings are consistent with Erikson's theory of generativity. The results indicate that the TPWD volunteers linked their environmental 
actions to making contributions to future generations, passing on knowledge and skills, personal growth, and leaving a legacy for the community and its natural resources. They have an outward perspective on working with others in a natural environment and have taken action to do so by their volunteer efforts. For example, volunteers felt that they had a responsibility to improve the neighborhood in which they live. The concept of neighborhood can certainly be broadened to include larger geographic areas which encompass the Texas state parks and programs in which they volunteer. These TPWD volunteers become key local community assets to protect the natural environment within and outside state parks through their individual commitment and the new networks they develop. In essence, they are not only concerned about using their expertise for their own personal fulfillment, but want to share what they know, and do with others now and into the next generation.

\subsection{Relationships between Motivations, Satisfaction, Commitment, and Generativity}

This research revealed that the benefits individuals obtained from volunteering significantly contributed to their satisfaction and yielded further positive commitment outcomes. The findings of this study are consistent with the previous functional analyses of nature-based volunteerism (e.g., $[23,54,67])$ that have documented how volunteer motivations significantly predict the satisfaction and the commitment of volunteer involvement. However, this study went beyond simply predicting satisfaction and commitment for volunteers.

One of the goals of this study was to use generativity in Erikson's psychosocial development theory as a framework for investigating individuals' experiences of environmental volunteerism. The results of this study showed that generativity was useful in explaining the variance of volunteer motivations, satisfaction, and commitment. This study contributes to the theoretical development of volunteer motivations because it pinpoints how certain types of volunteers feel about what they do, especially as it relates to the natural environment. Conceptually, the use of generativity for examining volunteer commitment adds to the literature by demonstrating that personal satisfaction and motivations ring true for volunteers, but more importantly, for those doing stewardship work and their view of the future.

In this study, individuals who had high levels of generativity were strongly motivated in ways that characterized them as consistent with volunteers who work in the natural environment (e.g., concern for the environment, eager for personal growth, and keen to express their values). In addition, the fulfillment of their generative concerns can lead to positive outcomes, such as committed and effective volunteers. These findings about generative concerns were also found by de Espanés et al. (2015) [18], which examined volunteers from five volunteer organizations in Argentina. Generativity predicted all of the motivational factors for volunteering, e.g., social, that were considered in their research. Thus, our findings help understand not only that generativity is an essential precursor of volunteerism, but also a key component toward commitment for stewardship work. In the case of TPWD, better connecting with volunteers will enhance local governance by getting locals to be more engaged as a concerned public and at the same time protect their local assets, e.g., wildlife, etc.

\section{Conclusions}

The current findings demonstrate that the goals served by volunteering, the volunteer experience, organizational commitment, and the features of generativity were all strongly associated with each other. The nature of these relationships have several implications for learning more about volunteers and improving stewardship-related programs, primarily for younger adults and those teaching in an environmental setting. In exploring these relationships further, the sample in this study is limited to one natural resource agency so there is a need to expand to other volunteer programs. Given the average age of this sample and its socio-demographic composition, no attempt is made to generalize these results beyond the volunteer program at the Texas Parks \& Wildlife Department (TPWD). Future research should examine volunteers at other types of agencies and organizations and even go beyond the U.S. in measuring the commitment of volunteers engaged in environmental stewardship 
internationally [74]. However, the results demonstrate the importance of generativity in understanding volunteer commitment and how it is can play a role in the education, teaching and recruitment of volunteers.

This study provides particular insight into the manner by which individuals derive meaning and fulfillment from volunteering in environmental stewardship activities, through the lens of Erikson's theory of generativity. Generativity-the desires of making contributions to future generations, passing on skills and knowledge, personal growth, and leaving a legacy-can also help us understand volunteerism in the environmental context. The fulfillment of generative desires has been reported as the motivator for involvement in other volunteer programs [18]. Therefore, it is important for TPWD to raise the environmental awareness of a whole community through information, education, and public discussion. These actions would contribute to a whole community's self-realization of the personal responsibility towards the improvement of the welfare of future generations [52,75]. TPWD should recognize its volunteers' desire and work to activate this participative commitment. Researchers (e.g., [14]) have found that generative concern usually peaks in the middle (around 40 to 59 years old) and later years. Therefore, the recruitment efforts for organizations and agencies should target midlife and older adults, especially when they want to get youth more involved in conservation and outdoor recreation. Compared to older adults, younger adults might not be in an ideal position to volunteer because of lack of time, family commitments, or limited capabilities in teaching youth about the environment [76]. More information should be obtained by the agency that is recruiting volunteers so as to learn more about why they want to volunteer, and the benefits they hope to attain, now and in the future. If agencies knew more about long-term benefits of those who volunteer, they might be able to provide more lasting programs that align with the volunteer and agency goals. Learning more about how volunteers view the local environment and next generation is what generativity is all about. This type of information will help TPWD work more effectively and help volunteers become more involved in local natural resource decision-making and enhance their community assets. Local groups, i.e., Friends of State Parks, may develop which will add to more local input and possibly boost revenue generation for the agency, e.g., donations.

More intergenerational activities that bring older adults together with teenagers and younger children should be designed to fulfill older volunteers' generative concern. For instance, volunteer educators could bring in groups of school-age children to assist park staff with environmental restoration projects and other needed projects. Through these types of foundational courses, youth may become more engaged in citizen science programs. These programs may help them better understand the relevance of environmental stewardship activities because more and more public agencies require restoration and monitoring data. Such opportunities would satisfy adult volunteers' desire to mentor and teach young people, promote intergenerational relations, and broaden the public's awareness and participation in stewardship activities [51,77]. These types of activities can also encourage pro-environmental behaviors for youth and possibly broaden the population that volunteers could educate [69].

Given the need to engage youth and retain older volunteers, recruitment communications of agencies (e.g., program webpage, Facebook page, or word of mouth) should emphasize the benefits to both organizations and volunteers so the message gets out to the most appropriate volunteer age groups. The messages could go out formally, e.g., via an agency or website, or informally through social networks [78]. Recruitment efforts to mobilize adult volunteers in environmental activities should also focus on reciprocal relationships. It has been found that adults gain benefits from the participation of generative action in several areas, including psychological and physical $[79,80]$. Recent volunteer programs have engaged older adults in environmental activities. Retirees in Service to the Environment (RISE) was founded on a model that recruits and trains older adults in environmental volunteering. This program strives to meet community stewardship needs, provides individual benefits to adults participants and at the same time, addressing barriers older adults may face in a structured program [81]. TPWD could more engaged with local communities, especially those people 
near state parks to better connect with residents. Given the history and vast experience that TPWD has in managing parks and natural resources, TPWD may also be able to provide guidance with volunteers beyond park management, e.g., fire mitigation or water quality.

In essence, not only will volunteers benefit from the volunteer experience but participants will as well. Participants will gain new knowledge, whether it is through learning about ecosystems or gaining perceptions of self; learning will take place at both ends [82]. Continued research is needed on the holistic benefits of participation in stewardship activities, beyond protecting the environment, in order to maximize its contribution to the individual, participants and the agency.

Author Contributions: Writing—original draft preparation, C.D.; writing—review and editing, M.A.S. All authors have read and agreed to the published version of the manuscript.

Funding: This research received no external funding.

Acknowledgments: The authors would like to thank the Texas Parks \& Wildlife Department for giving the researchers access to their volunteer database.

Conflicts of Interest: The authors declare no conflict of interest.

\section{References}

1. Musick, M.A.; Wilson, J. Volunteers: A Social Profile; Indiana University Press: Bloomington, Indiana, 2008.

2. Bureau of Labor Statistics. Volunteering in the United States-2015. 2016. Available online: http: //www.bls.gov/news.release/pdf/volun.pdf (accessed on 10 January 2017).

3. Corporation for National and Community Service. Volunteering and Civic Life in America, National, State, and City Information. 2015. Available online: http://www.volunteeringinamerica.gov/ (accessed on 10 January 2017).

4. Wells, P.M. Volunteer Motivation, Satisfaction, and Continuance: The Role of Training. Master's Thesis, San Jose State University, San Jose, CA, USA, 2005.

5. Pagès, M.; Fischer, A.; van der Wal, R. The dynamics of volunteer motivations for engaging in the management of invasive plants: Insights from a mixed-methods study on Scottish seabird islands. J. Environ. Plan. Manag. 2018, 61, 904-923. [CrossRef]

6. Silverberg, K.E. Understanding American parks and recreation volunteers utilizing a functionalist perspective. In Volunteering as Leisure/Leisure as Volunteering: An International Assessment; Stebbins, R.A., Graham, M., Eds.; CABI: Wallingford, UK, 2004; pp. 87-110.

7. Bruyere, B.; Rappe, S. Identifying the motivations of environmental volunteers. J. Environ. Plan. Manag. 2007, 50, 503-516. [CrossRef]

8. NPS (National Park Service). NPS Deferred Maintenance Reports. 2015. Available online: https://www.nps. gov/subjects/plandesignconstruct/defermain.htm (accessed on 20 January 2017).

9. Leslie, L.L.; Velez, C.E.; Bonar, S.A. Utilizing volunteers on fisheries projects: Benefits, challenges, and management techniques. Fisheries 2004, 29, 10-14. [CrossRef]

10. Fisher, D.L.; Connolly, J.J.; Svendsen, E.S.; Campbell, L.K. Digging Together: Why People Volunteer to Help Plant One Million Trees in New York City. 2011. Available online: http://nrs.fs.fed.us/nyc/local-resources/ downloads/ (accessed on 13 November 2016).

11. Foster, A. Volunteer environmental stewardship and affective labour in Philadelphia. Conserv. Soc. 2018, 16, 52-63. [CrossRef]

12. Cannistraro, M.; Lorenzini, E. The Applications of the New Technologies E-Sensing in Hospitals. Dev. Res. 2016, 34, 551-557. [CrossRef]

13. Cannistraro, M.; Cannistraro, G.; Chao, J.; Ponterio, L. New Technique Monitoring and Transmission Environmental Data with Mobile. Instrum. Mes. Metrol. 2018, 18, 549-562. [CrossRef]

14. Erikson, E.H. Childhood and Society; W. W. Norton Company, Inc.: New York, NY, USA, 1963.

15. Urien, B.; Kilbourne, W. Generativity and self-enhancement values in eco-friendly behavioral intentions and environmentally responsible consumption behavior. Psychol. Mark. 2011, 28, 69-90. [CrossRef]

16. Hart, H.M.; McAdams, D.P.; Hirsch, B.J.; Bauer, J.J. Generativity and social involvement among African Americans and White adults. J. Res. Personal. 2001, 35, 208-230. [CrossRef] 
17. Rossi, A.S. Contemporary dialogue on civil society and social responsibility. In Caring and Doing for Others: Social Responsibility in the Domains of Family, Work, and Community; Rossi, A.S., Ed.; University of Chicago Press: Chicago, IL, USA, 2001; pp. 3-72.

18. de Espanés, G.M.; Villar, F.; Urrutia, A.; Serrat, R. Motivation and commitment to volunteering in a sample of Argentinian adults: What is the role of generativity? Educ. Gerontol. 2015, 41, 149-161. [CrossRef]

19. Kapos, V.; Balmford, A.; Aveling, R.; Bubb, P.; Carey, P.; Entwistle, A.; Manica, A. Calibrating conservation: New tools for measuring success. Conserv. Lett. 2008, 1, 155164. [CrossRef]

20. Margoluis, R.; Stem, C.; Salafsky, N.; Brown, M. Design alternatives for evaluating the impact of conservation projects. New Dir. Eval. 2009, 122, 85-96. [CrossRef]

21. Weston, M.; Fendley, M.; Jewell, R.; Satchell, M.; Tzaros, C. Volunteers in bird conservation: insights from the Australian Threatened Bird Network. Ecol. Manag. Restor. 2003, 4, 205-211. [CrossRef]

22. Measham, T.G.; Barnett, G.B. Environmental volunteering: Motivations, modes and outcomes. Aust. Geogr. 2008, 39, 537-552. [CrossRef]

23. Jacobson, S.K.; Carlton, J.S.; Monroe, M.C. Motivation and satisfaction of volunteers at a Florida Natural Resource Agency. J. Park Recreat. Adm. 2012, 30, 51-67.

24. Schuett, M.A.; Taggart, M.; Mitchell, M. Examining Forest Service Volunteers in the Southern Region 2010-2015. Presented at the Society of American Foresters Convention, Madison, WI, USA, 2-6 November 2016.

25. Bang, H.; Ross, S.D. Volunteer motivation and satisfaction. J. Venue Event Manag. 2009, 1, 61-77.

26. Phillips, M. Motivation and expectation in successful volunteerism. J. Volunt. Action Res. 1982, 11, 118-125. [CrossRef]

27. Chinman, M.J.; Wandersman, A. The Benefits and Costs of Volunteering in Community Organizations: Review and Practical Implications. Nonprofit Volunt. Sect. Q. 1999, 28, 46-64. [CrossRef]

28. Smith, M.; Bruner, J.; White, R. Opinions and Personality; Wiley: New York, NY, USA, 1956.

29. Katz, D. The functional approach to the study of attitudes. Public Opin. Q. 1960, 24, 163-204. [CrossRef]

30. Clary, E.G.; Ridge, R.D.; Stukas, A.A.; Snyder, M.; Copeland, J.; Haugen, J.; Miene, P. Understanding and assessing the motivations of volunteers: A functional approach. J. Personal. Soc. Psychol. 1998, 74, 1516-1530. [CrossRef]

31. Asah, S.T.; Blahna, D.J. Practical implications of understanding the influence of motivations on commitment to voluntary urban conservation stewardship. Conserv. Biol. 2013, 27, 866-875. [CrossRef]

32. Schuett, M.A.; Kyle, G.T.; Leitz, J.; Kurzawski, K.; Lee, K. Anglers' motivations for volunteering with fishing or conservation organizations. Fisheries 2014, 39, 305-311. [CrossRef]

33. Wright, D.R.; Underhill, L.G.; Keene, M.; Knight, A.T. Understanding the motivations and satisfactions of volunteers to improve the effectiveness of citizen science programs. Soc. Nat. Resour. 2015, 28, 1013-1029. [CrossRef]

34. Dresner, M.; Handelman, C.; Braun, S.; Rollwagen-Bollens, G. Environmental identity, pro-environmental behaviors, and civic engagement of volunteer stewards in Portland area parks. Environ. Educ. Res. 2015, 21, 991-1010. [CrossRef]

35. Follman, J.M. Co-Coordinated Volunteer Programs at U.S. National Parks: A multi-Case Study of Volunteer Partnerships. Ph.D. Thesis, The George Washington University, Washington, DC, USA, 2015.

36. Galindo-Kuhn, R.; Guzley, R.M. The volunteer satisfaction index: Construct definition, measurement, development, and validation. J. Soc. Serv. Res. 2001, 28, 45-68. [CrossRef]

37. Cheung, F.Y.L.; Yan, E.C.W.; Tang, C.S.K. Factors influencing intention to continue volunteering: A study of older Chinese in Hong Kong. J. Soc. Serv. Res. 2006, 32, 193-209. [CrossRef]

38. Bang, H. Volunteer age, job satisfaction, and intention to stay: A case of nonprofit sport organizations. Leadersh. Organ. Dev. J. 2015, 36, 161-176. [CrossRef]

39. Penner, L.A. Dispositional and organizational influences on sustained volunteerism: An interactionist perspective. J. Soc. Issues 2002, 58, 447-467. [CrossRef]

40. Hunter, A.T. Why volunteer for the environment? An exploration of environmental volunteer motivation, satisfaction and retention. Proc. Natl. Acad. Sci. USA 2010, 107, 14321-14326.

41. Bussell, H.; Forbes, D. The volunteer life cycle: A marketing model for volunteering. Volunt. Action 2003, 5,61 . 
42. Green, B.C.; Chalip, L. Paths to volunteer commitment: Lessons from the Sydney Olympic games. In Volunteering as Leisure/Leisure as Volunteering: An International Assessment; Graham, M., Stebbins, R.A., Eds.; CABI: Wallingford, UK, 2004; pp. 49-67.

43. Perugini, M.; Conner, M.; O'Gorman, R. Automatic activation of individual differences: A test of the gatekeeper model in the domain of spontaneous helping. Eur. J. Personal. 2011, 25, 465-476. [CrossRef]

44. Aydinli, A.; Bender, M.; Chasiotis, A.; Cemalcilar, Z.; van de Vijver, F.J. When does self-reported prosocial motivation predict helping? The moderating role of implicit prosocial motivation. Motiv. Emot. 2014, 38, 645-658. [CrossRef]

45. Aydinli, A.; Bender, M.; Chasiotis, A.; van de Vijver, F.J.; Cemalcilar, Z.; Chong, A.; Yue, X. A cross-cultural study of explicit and implicit motivation for long-term volunteering. Nonprofit Volunt. Sect. Q. 2016, 45, 375-396. [CrossRef]

46. Erikson, E.H. The Life Cycle Completed: A Review; W. W. Norton Company, Inc.: New York, NY, USA, 1982.

47. Son, J.; Wilson, J. Generativity and volunteering. Sociol. Forum 2011, 26, 644667. [CrossRef]

48. Wells, N.M.; Pillemer, K. Environmental engagement in later life. In Fostering Reasonableness: Supportive Environments for Bringing Out Our Best; Kaplan, R., Basu, A., Eds.; Michigan Publishing, University of Michigan Library: Ann Arbor, MI, USA, 2015; pp. 157-175.

49. McAdams, D.P. Generativity in midlife. In Handbook of Midlife Development; Lachman, M.E., Ed.; Wiley Series on Adulthood and Aging; John Wiley Sons Inc.: Hoboken, NJ, USA, 2001; pp. 395-443.

50. Snyder, M.C.; Clary, E.G. Volunteerism and the generative society. In The Generative Society: Caring for Future Generations; de St Aubin, E.E., McAdams, D.P., Kim, T.-C., Eds.; American Psychological Association: Washington, DC, USA, 2004; pp. 221-237.

51. Warburton, J.; Gooch, M. Stewardship volunteering by older Australians: The generative response. Local Environ. 2007, 12, 43-55. [CrossRef]

52. Cossetta, A.; Cappelletti, P. Participation as a product of generativity. Presented at the International Conference "Participatory Local Welfare, Citizenship and Third Sector Organizations. What is at stake?", Pisa, Italy, 31 January-1 February 2013.

53. Texas Parks and Wildlife. n.d.a. General Information about TPWD. Available online: https://tpwd.texas.gov/ about (accessed on 22 January 2017).

54. Ryan, R.L.; Kaplan, R.; Grese, R.E. Predicting volunteer commitment in environmental stewardship programmes. J. Environ. Plan. Manag. 2001, 44, 629-648. [CrossRef]

55. Allen, N.J.; Meyer, J.P. The measurement and antecedents of affective, continuance and normative commitment to the organization. J. Occup. Psychol. 1990, 63, 1-18. [CrossRef]

56. McAdams, D.P.; de St. Aubin, E.D. A theory of generativity and its assessment through self-report, behavioral acts, and narrative themes in autobiography. J. Personal. Soc. Psychol. 1992, 62, 1003-1015. [CrossRef]

57. Anderson, J.C.; Gerbing, D.W. Structural equation modeling in practice: A review and recommended two-step approach. Psychol. Bull. 1988, 103, 411-423. [CrossRef]

58. Bentler, P.M. On the fit of models to covariances and methodology to the Bulletin. Psychol. Bull. 1992, 112, 400-404. [CrossRef]

59. Steiger, J.H.; Lind, J.C. Statistically-based Tests for the Number of Common Factors. Presented at the Annual Spring Meeting of the Psychometric Society, Iowa City, IA, USA, 30 May 1980.

60. Bentler, P.M.; Bonnett, D.G. Significance tests and goodness of fit in the analysis of covariance structures. Psychol. Bull. 1980, 88, 588-606. [CrossRef]

61. Hu, L.T.; Bentler, P.M. Fit indices in covariance structure modeling: Sensitivity to underparameterized model misspecification. Psychol. Methods 1998, 3, 424-453. [CrossRef]

62. Litwin, M. How to Measure Survey Reliability and Validity; Sage Publishing Inc.: Thousand Oaks, CA, USA, 1995.

63. MacCallum, R.C.; Browne, M.W.; Sugawara, H.M. Power analysis and determination of sample size for covariance structure modeling. Psychol. Methods 1996, 1, 130-149. [CrossRef]

64. Scott, J.P.; Reifman, A.; Mulsow, M.; Feng, D. Program evaluation of "Young at Heart": Examining elderly volunteers' generativity. J. Intergenerational Relatsh. 2003, 1, 25-33. [CrossRef]

65. Vuksanovic, D.; Dyck, M.; Green, H. Development of a brief measure of generativity and ego-integrity for use in palliative care settings. Palliat. Supportive Care 2015, 13, 1411-1415. [CrossRef] [PubMed] 
66. Bandalos, D.L. Finney, S.J. Item parceling issues in structural equation modeling. In New Developments and Techniques in Structural Equation Modeling; Marcoulides, G.A., Schumacker, R.E., Eds.; Lawrence Erlbaum Associates Inc.: Mahwah, NJ, USA, 2001; pp. 269-296.

67. Asah, S.T.; Blahna, D.J. Motivational functionalism and urban conservation stewardship: Implications for volunteer involvement. Conserv. Lett. 2012, 5, 470-477. [CrossRef]

68. Hauser, B.K.; Koontz, T.M.; Bruskotter, J.T. Volunteer participation in collaborative watershed partnerships: insights from the Theory of Planned Behavior. J. Environ. Plan. Manag. 2011, 55, 77-94. [CrossRef]

69. Sander-Regier, R. The Power of a Small Green Place-A case study of Ottawa's Fletcher Wildlife Garden. Ph.D. Thesis, The University of Ottawa, Ottawa, ON, Canada, 2013.

70. Pearce, J.L. Job attitude and motivation differences between volunteers and employees from comparable organizations. J. Appl. Psychol. 1983, 68, 646-652. [CrossRef]

71. Evans, E.; Ching, C.C.; Ballard, L.H. Volunteer guides in nature reserves: Exploring environmental educators' perceptions of teaching, learning, place and self. Environ. Educ. Res. 2012, 18, 391-402. [CrossRef]

72. Van Den Berg, H.A.; Dann, S.L.; Dirkx, J.M. Motivations of adults for non-formal conservation education and volunteerism: Implications for programming. Appl. Environ. Educ. Commun. 2009, 8, 6-17. [CrossRef]

73. Laird, S.G.; Nelson, S.A.C.; Stubbs, H.S.; James, A.L.; Menius, E. Organizational structures and data use in volunteer monitoring organizations (VMOs). Appl. Environ. Educ. Commun. 2012, 11, 165-177. [CrossRef]

74. McDougle, L.; Handy, F.; Katz-Gerro, T.; Greenspan, I.; Lee, H. Factors predicting proclivity and intensity to volunteer for the environment in the US and South Korea. J. Environ. Plan. Manag. 2015, 58, 837-854. [CrossRef]

75. Taylor, A.S. Generativity and adult development: implications for mobilizing volunteers in support of youth. In Mobilizing Adults for Positive Youth Development; Clary, E.G., Rhodes, J.E., Eds.; Springer: Boston, MA, USA, 2006; pp. 83-99.

76. McAdams, D.P.; Logan, R. What is Generativity. In The Generative Society. Caring for Future Generations; de St Aubin, E.E., McAdams, D.P., Kim, T., Eds.; American Psychological Association: Washington, DC, USA, 2004.

77. Liu, S.; Kaplan, M.S. An intergenerational approach for enriching children's environmental attitudes and knowledge. Appl. Environ. Educ. Commun. 2006, 5, 9-20. [CrossRef]

78. Church, S.P.; Payne, L.B.; Peel, S.; Prokopy, L.S. Beyond water data: Benefits to volunteers and to local water from a citizen science program. J. Environ. Plan. Manag. 2019, 62, 306-326. [CrossRef]

79. Keyes, C.L.M.; Ryff, C.D. Generativity in adult lives: Social structural contours and quality of life consequences. In Generativity and Adult Development: How and Why We Care for the Next Generation; McAdams, D., de. St. Aubin, E., Eds.; American Psychological Association: Washington, DC, USA, 1998; pp. 227-264.

80. Putnam, R.D. Bowling Along: The Collapse and Revival of American Community; Simon Schuster: New York, NY, USA, 2000.

81. Pillemer, K.; Wells, N.W.; Meador, R.H.; Schultz, L.; Henderson, C.H., Jr.; Cope, M.T. Engaging older adults in environmental Volunteerism: The retirees in service to the environment program. Gerontologist 2017, 57,367-375. [CrossRef] [PubMed]

82. Rickinson, M.; Lundholm, C.; Hopwood, N. Environmental Learning; Insights from Research into the Student Experience; Springer: New York, NY, USA, 2009.

(C) 2020 by the authors. Licensee MDPI, Basel, Switzerland. This article is an open access article distributed under the terms and conditions of the Creative Commons Attribution (CC BY) license (http://creativecommons.org/licenses/by/4.0/). 